\title{
HUKUM ISTRI MENCARI NAFKAH DALAM TINJAUAN MAQASHID SYARIAH
}

\author{
Elimartati \\ LAIN Batusangkar,elimartati@iainbatusangkar.ac.id
}

Diterima: 20 September $2018 \quad$ Direvisi: 17 November $2018 \quad$ Diterbitkan: 30 Desember 2018

\begin{abstract}
In common tradition, making a living is a busband's obligation, but now many wives play a role in earning a living. The aim of the study was to find out the law of the wife looking for a nafka, viewed the condition and ability of the husband to provide a living, in the review of Maqashid Shari'a proposed by Syatibi. The influence of science and technology and the increase in bousehold needs triggers many wives to take part in making a living, and become the main breadwinner. This certainly raises the question, how does the view of Islamic law on wives earn a living in library research, using the normative qualitative method of gender analysis approach is content analysis. Islamic law explains that a wife cannot leave her house without her husband's permission and her main task is at home. This certainly raises the question, how does the view of Islamic law on wives earn a living. The results of the study explain that wife's law makes a varied living circumcision, makhruh and haram based on the ability of the husband to provide bis wife with the benefit and the level of family needs (maqashid).
\end{abstract}

Keywords: Istri pencari nafkah, maqashsid syariah, bokum

\begin{abstract}
Abstrak
Umumnya, mencari nafkah adalah kewajiban suami, namun sekarang banyak istri yang berperan mencari nafkah. Tujuan penelitian mengetabui bukum istri mencari nafka dilibat kondisi dan kemampuan suami memberi nafkah, dalam tinjauan maqashid syariah yang dikekemukakan Syatibi. Pengaruh iptek dan peningkatan kebutuban rumah tangga pemicu banyaknya istri ikut mencari nafkah, dan menjadi pencari nafkah utama. Hal ini tentunya menimbulkan pertanyaan, bagaimana pandangan bukum Islam terbadap istri mencari nafkah Jenis penelitian kepustakaan (library research), dengan memakai metode kualitatif normativ pendekatan analisis gender bersifat conten analisis. Hukum Islam menjelaskan istri tidak boleh keluar rumah tanpa izin suaminya dan tugas pokoknya adalah dirumah tangga. Hal ini tentu menimbulkan pertanyaan, bagaimana pandangan bukum Islam terbadap istri mencari nafkah. Hasil penelitian menjelaskan bukum istri mencari nafkah bervariasi sunat, makhruh dan haram berdasarkan kemampuan suami memberi nafkah kepada istrinya dilihat dari kemaslahatan dan tingkat kebutuhan kelurga (maqashid).
\end{abstract}

Kata Kunci: Istri pencari nafkah, maqashsid syariah, bukum

\section{PENDAHULUAN}

Kewajiban nafkah oleh suami kepada istrinya menurut Sayyid Sabiq (1983:148) karena adanya ikatan perkawinan yang sah maka istri menjadi terikat dengan adanya hak suami padanya, dan tertahan sebagai miliknya, karena suami berhak bersenang-senang dengannya, dan istri harus mengikuti keinginan suaminya, tinggal dirumah, mengatur rumah tangga, memelihara dan mendidik anak. Sebaliknya suami berkewajiban memenuhi kebutuhan istrinya (nafkah), selama ikatan 
suami istri masih berjalan dan istri tidak nusyuz:peningkatan kebutuhan rumah tangga dan beraneka ragamnya keinginan anggota keluarga, mendorong perempuan sebagai istri untuk ikut menambah penghasilan suami, bahkan banyak juga keluarga yang istri berperan utama mencari nafkah. Hal ini tentu menimbulkan pertanyaan, apakah ada kewajiban istri mencari nafkah, dan bagaimana ketentuan hukum yang berlaku terhadap istri sebagai pencari nafkah. Permasalahan di atas membahas Hukum istri mencari nafkah bervariasi sunat, makhruh dan haram berdasarkan kemampuan suami memberi nafkah kepada istrinya dilihat dari kemaslahatan dan tingkat kebutuhan kelurga (maqashid syariah).

Pada dasarnya inti dari tujuan syarîat (hukum) atau Maqâshid al-Syarîa adalah kemaslahatan umat manusia. Berkaitan dengan ini al-Syâthibi menyatakan bahwa: "sesunggubnya syâri" (pembuat sharîat) dalam mensyari'atkan hukum bertujuan untuk mewujudkan kemaslahatan hamba baik di dunia maupun di akhirat secara bersamaan".

\section{METODE PENELITIAN}

Penelitian ini merupakan pranata sosial yang berkaitan dengan yuridis formal. Jenis yang digunakan dalam penelitian ini adalah penelitian perpustakaan. Metode yang digunakan kualitatif normatif, dengan pendekatan analisis gender. penelitian bersifat conten analisis yang bersumber data sekunder, dibagi menjadi bahan hukum primer, sekunder, dan hukum tersier. Mendudukan masalah hukum tentang istri mencari nafkah penulis lakukan dengan memakai metode istimbat hukum yaitu menetapkan hukumnya berdasarkan ayat-ayat Alquran, yakni menginventaris ayat-ayat yang menjadi dalil hukum dan manafsirkan dengan berlandaskan pendapat para mufasir. Kemudian menginventaris Hadis-hadis Rasulullah SAW. yang menjadi dasar hukum dari masalah yang ditetapkan hukumnya. Mengambil kaedah hukum yang menjadi dalil pelengkap dari dalildalil di atas. Dalam hal yang belum jelas hukumnya ditetapkan berdasasarkan dalil di atas, maka melihat dalil- dalil hukum yang dipakai para ulama dalam mengistimbatkan hukum, dengan melihat kemaslahatan dan tingkat kebutuhan sebagai standar penetapan hukum dengan teori maqashid syariah yang dikekemukakan Syatibi.

\section{PEGERTIAN MAQASHID SYARIAH}

Allah swt sebagai pembuat shari'at tidak menciptakan suatu hukum dan aturan di muka bumi ini tanpa tujuan dan maksud begitu saja, melainkan hukum dan aturan itu diciptakan dengan tujuan dan maksud tertentu. Shari'at diturunkan oleh Allah pada dasarnya bertujuan untuk mewujudkan kemaslahatan hamba sekaligus untuk menghindari kerusakan, baik di dunia maupun di akhirat.

Semua perintah dan larangan Allah yang terdapat dalam Alquran, begitu pula perintah dan larangan Nabi Muhammad SAW yang ada dalam Hadits, yang diasumsikan ada keterkaitan dengan hukum memberikan kesimpulan bahwa semuanya mempunyai tujuan tertentu dan tidak ada yang sia-sia. Semuanya mempunyai hikmah yang mendalam, yaitu sebagai rahmat bagi umat manusia. Maqashid Syariah sering dipahami dengan maksud / tujuan dan sasaran syariat (Syatibi, 1992: 265) (goal and objective of Islamic law)

Maqashid Syariab tumbuh bersamaan dengan kehadiran syariat Islam, maka perhatian ulama terhadap maqshidsyariah telah muncul semenjak generasi awal. Para imam mujtahid tidak mengabaikannya. Bahkan Imam Ahmad bib Hanbal memandang bahwa ijtihad dengan mempergunakan nalar kiasmerupakan bagian dari memahami maksud syara'.

Wahbah al-Zuhaili, (1986: 225) mengatakan bahwa maqâshid al-syarîah adalah nilai-nilai dan sasaran syara' yang tersirat dalam 
segenap atau bagian terbesar dari hukumhukumnya. Nilai-nilai dan sasaran-sasaran itu dipandang sebagai tujuan dan rahasia syarî’ah, yang ditetapkan oleh al-Syâri' (pembuat syari'at yaitu Allah dan Nabi Muhammad) dalamsetiap ketentuan hukum. Sementara al-Syâthibi, (1992) menyatakan bahwa beban-beban syarî’ah kembali pada penjagaan tujuantujuanya pada makhluk. Tujuan-tujuan ini tidak lepas dari tiga macam: dlarûriyyât, bâjizyât dan tabsiniyyât. Al-Syâri' memiliki tujuan yang terkandung dalam setiap penentuan hukum untuk mewujudkan kemaslahatan manusia di dunia dan di akhirat.

Terlepas dari perbedaan pendapat dalam mendefinisikan maqâshid al-syarî’ah tersebut, para ulama ushûl al-fiqh sepakat bahwa maqâshid al-syarî'ah adalah tujuantujuan akhir yang harus terealisasi dengan diaplikasikanya syarîat.(Mohammad Darwis, dalam Ali Mutakin, 2017 :552),pengaplikasian syarî'at dalam kehidupan nyata (dunia), adalah untuk menciptakan kemaslahatan atau kebaikan para makhluk di muka bumi.

Izzudin bin Abdi Salam (1999: 11) mengatakan Syariah (hukum Islam) seluruhnya merupakan maslahat, adakalanya hukum tersebut diletakan untuk menolak kerusakan, dan ada yang membawa kemaslahatan yang baru. Contohnya Allah memulai ayat dalam Alquran dengan "bai orang beriman", perhatikanlah lanjutan penjelasannya adalah mengajak kepada kebaikan dan menjelakan agar tidak jatuh kepada perbuatan kejahatan. Artinya ayat berisi gabungan peringatan dan anjuran. Izzudin mendifinisikan maqashid Syariah dengan mendatangkan manfaat serta penyebabnya bagi umat, dan menolak kerusakan bersama faktor- faktornya untuk kehidupan dunia dan akhirat atau mengabungkan kedua urusan tersebut.

Ungkapan di atas dapa dipahami bahwa maksud peletakan hukum membawa maslahat atau menolak kerusakan atau mengabungkan kedua perkara untuk hamba
Allah SWT. Apabilamaksud hukum sudah diketahui maka akan menghasilkan manfaat dan menolak kemudaratan untuk kehidupan dunia dan akhirat.

Hasil telaahan ulama ushul dapat dijelaskan bahwa :

1. Ulama terdahulu (salaf) mempunya pola pikir yang saling berdampingan memberikan defines imaqashid Syariah dan fungsi hukum di dalammnya. Maksud Syariah di fokuskan pada pemeliharaan maslahat dan menolak kerusakan di dunia yang akan dirasakan akibatnya di akhirat nanti.

2. Kecendrungan kepada penetapan hukum syara' yang terkait dengan hikmah dan tujuan, apakah dapat diketahui atau tidak. Yusuf Qardhawi (1996: 113-114) menegaskan bahwa fuqaha' muslim telah sepakat dalam masalah ini, hukum syara' mempunyai illat dan pemahan (hikmah) yang terkait dengan maslahat orang banyak, hal ini disepakati oleh umat Islam kecuali sekelompok kecil yang terdiri dari ahli Zabir dan orang yang berpola pikir seperti mereka. Pendapat ini di dukung oleh Fathi Duraini.

Al-Juwaini, Ushâliyyin kontemporer dianggap sebagai ahli ushûl al-fiqh pertama yang menekankan pentingnya memahami Maqâshid al-Syarîab dalam penetapkan sebuah hokum karya yang berjudul al-Burhân fîUshûl al-Ahkâm beliau mengembangkan kajian Maqâshid al-Syarî‘ah dengan mengelaborasi kajian 'illat dalam qiyâs. Menurutnya asal yang menjadi dasar 'illat dibagi menjadi tiga; yaitu: Dlarûriyyât, Hâjiyyât dan Makramât yang dalam istilah lain disebut dengant ahsîniyyât. Kerangka berfikir al-Juwaini tersebut dikembangkan oleh muridnya Muhammad bin Muhammad al-Ghazali (w. 505 H). karyanya; Syifâ al-Ghalîl, al-Mushthafâ min 'Ilmi alUshûl beliau merinci maslahat sebagai inti dari maqâshid al-syarî'ah menjadi lima, yaitu: 
memelihara agama, jiwa, akal, keturunan dan harta. Kelima maslahat ini berada pada tingkat yang berbeda sesuai dengan skala prioritas maslahat tersebut. Oleh karena itu beliau membedakanya menjadi tiga kategori; yaitu: peringkat dlarûriyyât, hajizyyât dan tahsiniyyât.

\section{PEMBAGIAN MAQASHID SYARIAH}

Syariat Islam, sebagaimana syari'at-syari'at lainnya bertujuan untuk memelihara butir-butir yang dikenal dengan istilah kulliyat al-khams (universalitas yang lima) dan al-dharuriyat alkhams (lima macam kepentingan vital), yaitu agama, jiwa, akal, keturunan dan harta. Cara untuk memelihara lima kepentingan ini, terdiri dari tiga tingkatan sesuai arti penting dan bahayanya. Tingkatan ini di kalangan ulama kita dikenal dengan al-dharuriyat, al-hajizat dan al-tahsiniyat. (Wahbah Az-Zuhaili, 1997:51)

1. Al-Dharuriyat

Adalah segala sesuatu yang tidak dapat ditinggalkan dalam kehidupan keagamaan dan keduniaan manusia. Dalam arti jika tidak ada maka kehidupan di dunia menjadi rusak, hilang kenikmatan, menghadapi siksaan di akhirat. Dalam Islam dharuriyat ini dijaga dari dua sisi yaitu realisasi dan perwujudan serta memelihara kelestariannya. (Wahbah Az-Zuhaili, 1997:51)

Sesuatu yang harus ada untuk keberadaan manusia atau tidak sempurna kehidupan manusia tanpa terpenuhinya kebutuhan tersebut. Kebutuhan yang bersifat primer ini dalam Ushul Fiqh disebut tingkat dharuri. (Amir Syarifuddin, 2009:222)

2. Al-Hajizat

Adalah sesuatu yang dibutuhkan oleh manusia dalam menghindari kesempitan dan menolak kesulitan. Yang mana jika ia tidak ada, akan membuat manusia mengalami kesempitan tanpa merusak kehidupan. (Wahbah Az-Zuhaili, 1997:52)

\section{Al-Tabsiniyat}

Adalah hal-hal yang menjadi tuntutan dari martabat diri dan akhlak yang mulia atau yang ditujukan untuk mendapatkan adat istiadat yang baik. Lingkupnya mencakup seluruh hal-hal terdahulu berupa ibadat, mua'malat, adat istiadat dan berbagai hukuman. (Wahbah Az-Zuhaili, 1997:52)

Sesuatu yang sebaiknya ada untuk memperindah kehidupan. Tanpa terpenuhinya kebutuhan tersier, kehidupan tidak akan rusak dan juga tidak akan menimbulkan kesulitan. Keberadaannya dikehendaki untuk kemuliaan akhlak dan kebaikan tata tertib pergaulan. (Amir Syarifuddin, 2009:228)

\section{ISTRI MENCARI NAFKAH DALAM TINJAUAN MAQASHID SYARI'AH}

Hukum Islam mengatur semua hal, bahkan hal keci sekalipun, apalagi soal harkat dan martabat perempuan, dalam Islam perempuan sangat dimuliakan. Sebelum datangnya Islam, perempuan diperlakukan semena-mena. Pada masa jahiliyah, bayi perempuan dikubur hidup-hidup karena dipandang bahwa perempuan hanya akan menyusahkan. Dalam Alquran sudah dijelaskan, yang artinya; "Apabila bayi-bayi perempuan yang dikubur hidup-bidup ditanya, karena dosa apakah dia dibunuh." (Q.s At-Takwir: 8-9)

Hukum Islam menjelaskan bahwa Kewajiban utama seorang istri adalah tetap tinggal dirumah suaminya, hal ini berlandaskan Al-quran surat al-Ahzab (33):

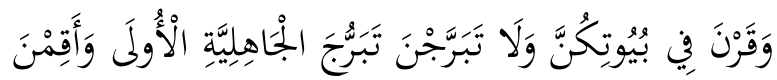

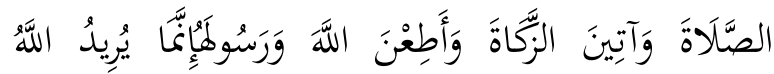

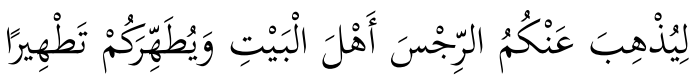
Dan hendaklah kamu tetap di rumahmu dan janganlah kamu berbias dan bertingkah laku seperti orang-orang Jabiliyah yang dabulu dan dirikanlah shalat, tunaikanlah zakat dan taatilah Allah dan Rasul-Nya. Sesunggubnya Allab bermaksud bendak. 
menghilangkan dosa dari kamu, Hai ablul bait dan membersibkan kamu sebersib-bersibnya.

Ulama tafsir berbeda pendapat memahami Kata Qarna awal dari berdasarkan cara membacanya ada yang membaca iqrarna, qurrt'ain qirna dan waqar yang berarti wibawa dan hormat, berarti perintah ayat dipahami untuk berada dirumah karena itu akan mendatangkan wibawa dan kehormatan buat kamu. (M.Quraish Shihab, 2004: 263.) AlQurtubi menuliskan makna ayat di atas merupakan perintah untuk menetap di rumah. Walaupun redaksi ayat ditujukan kepada istri Nabi, selain dari mereka juga tercakup dalam perintah ini. Agama penuh dengan tuntunan agar perempuan -perempuan tinggal dirumah mereka dan tidak keluar kecuali karena darurat. (Al-Qurtubi,1967: 3) Pendapat yang sama dikemukakan oleh ibnu al-'Arabi.(Al'Arabi,1957: 1523), pendapat ini juga dikemukakan olehIbnu Kasir (1986: 93). Pandangan yang berbeda diberikan oleh Sayyid Qutub dan Quraish Shihab dalam tafsir Fi Zilalil Qur'an, Sayyid Qutub menyatakan ayat tersebut memberi isyarat bahwa rumah tangga adalah tugas pokok istri, sedangkan selain itu tempat ia tidak menetap artinya tidak tugas pokoknya. Quraish Shihab cendrung mendukung pendapat Sayyid Qutub dengan memberikan argumen tambahan yang dikutip cendikiawan Mesir lainnya, Muhammad Qutub, menyatakan bahwa perempuan pada awal zaman Islam ada yang bekerja, ketika kondisi menuntut mereka untuk bekerja. Masalahnya bukan terletak pada ada atau tidak adanya hak mereka untuk bekerja, melainkan disebabkan hukum Islam tidak cenderung mendorong perempuan keluar rumah, kecuali untuk pekerjaan- pekerjaan yang sangat perlu yang dibutuhkan oleh masyarakat, atau atas dasar kebutuhan khusus perempuan. Misalnya kebutuhan untuk bekerja karena tidak ada yang membiayai hidupnya, atau suaminya tidak mampu untuk mencukupi kebutuhannya. (M.Quraish Shihab,1996: 304 .)
Menganalisis ayat dan pendapat di atas dapat dipahami ada tiga pendapat tentang boleh istri keluar rumah untuk bekerja. Pertama tidak membolehkan kecuali karena darurat hukumnya haram, kedua dibolehkan tetapi mengutamakan tugas dirumah tangga hukumnya makhruh, ketiga boleh tetapi lebih utama tinggal dirumah, hukumnya sunat. Berikut penjelasannya.

Sebelum memutuskan untuk bekerja di luar rumah, ada baiknya melihat pada beberapa faktor syar'i yang mendorong seorang muslimah untuk bekerja di luar rumah antara lain: pertama suami kesulitan memberi nafkah untuk istri dan keluarganya. Syariat memberi pilihan bagi istri yang suaminya tidak mampu memberi nafkah antara mengajukan fasakh atau tetap bertahan sebagai istri, Kedua suami dengan pendapatan terbatas sementara istri punya kemampuan untuk membantu suami. Akhirnya kondisi ini mendorong istri bekerja untuk mendapatkan materi yang bisa meningkatkan taraf hidup pribadi dan keluarga atas kerelaan hatinya. Ketiga istri memiliki utang yang harus dilunasi sehingga istri terdorong bekerja demi mendapatkan uang untuk menutup utang tersebut.

Kedudukan suami dengan istri dalam rumah tangga tidak persis sama, sangat ditentukan oleh kemampuan (sumber daya manusianya). Bisa saja terjadi perlimpahan sebahagian fungsi di antara keduanya, manakala hal itu baik dan menunjang dinamika mereka di rumah tangga, untuk membina keluarga sakinah mawaddah wa rahmah. Seperti perempuan ikut membantu pencari nafkah keluarga. Hukum asal istri mencari nafkah di luar rumah tangganya adalah ibahah (boleh), karena masalah ini tidak ada nash secara jelas yang mengaturnya. Tidak ada larangan dan juga tidak ada suruhan. Hal ini berdasarkan kaedah fikih; "Hukum asal dalam segala hal adalah boleh, bingga ada dalil yang menunjukkean akan keharamannya”.(Fatwa DSN No: 22/2002) 
Menetapkan hukum istri bekerja mencari nafkah akan dipengaruhi oleh kemampuan suami menafkahi istri dan anakanaknya, dipengaruhi oleh niat istri bekerja, keadaan rumah tangganya, terpenuhi syaratsyarat istri bekerja di luar rumah dan akibat yang ditimbulkan dari istri meninggalkan keluarga saat bekerja.Istri bekerja mencari nafkah merupakan solusi membantu suami mengatasi ketidak mampuan memenuhi kebutuhan keluarga. merupakan faktor utama untuk memperoleh penghasilan dan unsur penting untuk memakmurkan anggota keluarga. Bila istri tidak ikut membantu maka akan menimbulkan kemudaratan bagi keluarganya. Maka dalam kondisi seperti ini sunat hukumnya istri untuk membantu pencari nafkah, guna menghilangkan kesulitan yang dihadapi oleh keluarganya. Hal ini diperkuat dengan hadis :

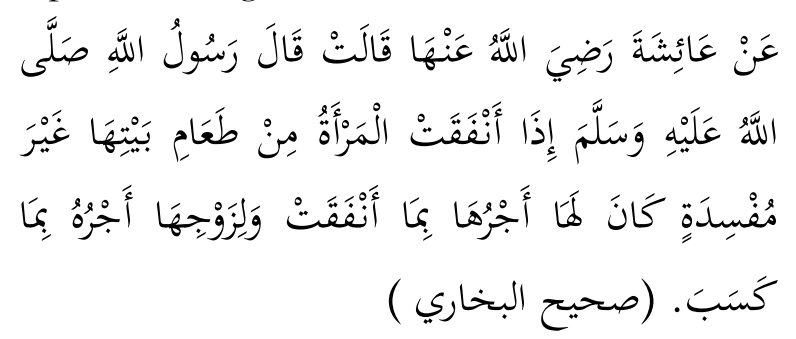

Dari Aisyah Ra ia berkata bahwa Rasulullah Saw bersabda, "Apabila seorang perempuan keluar dari rumah suaminya untuk mencari nafkah guna membantu suaminya dengan tidak menimbulkan kerusakan maka ia mendapat pabala dari apa yang ia usabakan." (HR: al-Bukbary,1987: 139)

Kaedah fikih menyebutkan; "bahaya itu menurut syara' harus di bilangkan", dan "Kebutuban 'itu ditempatkan pada tempat darurat, baik bersifat umum atau khusus."(Wahbah Zuahaili,1997:284). Kebutuhan keluarga yang dipenuhi oleh istri hanya setinggkat hajat, tidak sampai ketingkat darurat. Kondisi suami tidak mampu mencari nafkah seperti sedang sakit, dapat cacat permanen, maka suami berada dalam kondisi fakir ia berhak menerima zakat. Dalam hal ini amil zakat berkewajiban memberi dia zakat. Bila istri tidak berusaha mencari nafkah, maka ia tidak dapat dituntut, karena istri posisinya penerima nafkah, tidak dalam posisi kewajiban memberi nafkah sebagaimana kewajiban suami.

$$
\text { Wahbah al-Zuhaili (1997: 295) }
$$

menjelaskan perbedaan tingkat kebutuhan darurat dengan hajat sebagai berikut:

1. Darurat lebih kuat dorongannya dari pada hajat. Darurat dibangun atas perinsip mengerjakan sesuatu untuk melepaskan diri dari tanggung jawab,tetapi manusia tidak dapat meninggalkanya. Hajat dibangun atas perinsip memberi kelapangan dan kemudahan dalam hal yang manusia dapat meninggalkannya. Seperti kewajiban mencari nafkah adalah suami, sedangkan istri hanya membantu disaat suami tidak berkesempatan.

2. Ketetapan hukum pengecualian yang telah matap karena darurat, pada umumnya merupakan pembolehan yang bersifat sementara bagi sesuatu yang dilarang berdasarkan nash secara jelas bahwa hal itu dilarang syara'. Adapun ketetapan ketetapan hukum yang dibangun di atas perinsip kebutuhan (hajat), maka itu pada umumnya tidak bertentangan dengan nash yang shareh (jelas). seperti suami tidak memberi nafkah dilarang dalam syara'. Artinya suami wajib membayar nafkah. Adapun ketetapan hukum yang dibangun atas perinsip hajat, pada umumnya tidak bertentangan dengan nash yang shariah (jelas). Hajat membolehkan yang dilarang untuk sementara.

Memberi nafkah kepada suami yang dalam keadaan susah, tidak ada pencarian, termasuk perbuatan yang sangat baik. Kalau suami- istri dapat saling mewarisi setelah salah satu meninggal, tentu juga dapat saling membantu dalam kesusahan. Hal ini juga berdasarkan ayat Alquran surat al-Baqarah ayat 233; "dan warispun berkewajian demikian. Hukum Islam mengajarkan setiap individu berkewajiban memerangi kemiskinan dengan cara bekerja dan berusaha. Namun dalam 
situasi tertentu ada orang lemah yang tidak sanggup bekerja seperti orang mendapat kecelakaan yang mengakibatkan cacat permanen. Atau dipecat dari pekerjaan, usahanya bangkrut dan lain-lain. Kondisi suami seperti ini akan terbantu bila istri sebagai perempuan karir. Perempuan sebagai ibu tidak akan sanggup melihat suami dan anak-anaknya merintih kelaparan, kehausan, dan terlantar sementara dia sanggup berusaha memberi nafkah pada kelurganya. Memenuhi kebutuhan kelurga dekat pahalanya dapat dua yakni pahala sedekah dan pahala silaturrahim sebagaimana telah dijelaskan dalam hadis Rasulullah SAW.

Tugas atau peran utama yang harus dijalankan oleh seorang perempuan yang sudah menikah sebagai istri dan ibu adalah mengurus rumah tangga, mendidik anak, menjaga harta suami. Istri yang sibuk bekerja di luar rumah tangga akan melalaikan tugas utamanya, maka hukum dia bekerja di luar rumah mencari nafkah adalah makhruh, apabila suaminya mempunyai kemampuan untuk menafkahi istri. Artinya alasan istri bekerja di luar rumah bukan dorongan untuk mencari nafkah keluarga, melainkan karena sekedar mencari eksistensi dirinya ditengah masyarakat, untuk meningkatkan status sosial dan menghindari rasa bosan di rumah atau mengisi waktu kosong. Ibnu Qayyib al Jauziyah mengatakan (1996) bahwa niat dapat merubah ketentuan hukum. Hukum asal istri mencari nafkah adalah boleh untuk membantu suaminya. Hal berlandaskan Hadis riwayat Bukhari tentang niat.

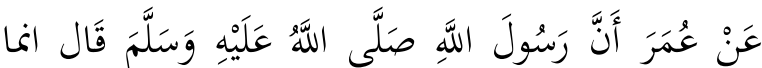

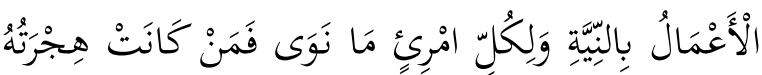

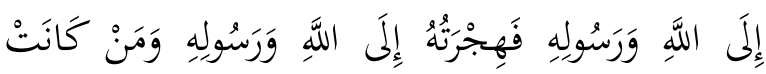

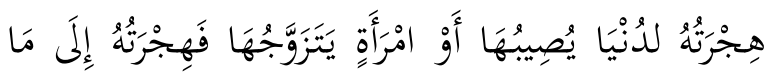

$$
\text { هَاجَرَ إِلَيْهِ (رواه البخاري) }
$$

Dari Umar bahwasanya Rasulullab Saw bersabda, Sesunggubnya setiap amalan bergantung kepada niat (pelakunya) dan setiap orang akan mendapatkan balasan tergantung kepada niatnya. Siapa yang berbijrab untuke Allab dan Rasul-Nya maka bijrabnya itu untuk. Allah dan Rasul-Nya. Siapa yang berbijrah untuk mendapatkan kenikmatan dunia ataupun untuk perempuan yang ingin dinikabinya maka hijrabnya itu kepada apa yang nijrabkan (niatkan) (HR. Bukhary)

Dalam sebuah kaedah fikih disebutkan bahwa "Segala urusan (perkara) bergantung kepada tujuannya, tidak ada pabala dan sanksi bila sesuatu dilakukan dengan tanpa niat" (Muhammad al-Ruki,tth:16). Bila istri yang bekerja di luar rumah tagganya akan menimbulkan masalah- masalah dalam rumah tangganya, maka istri harus mengutamakan keharmonisan keluarganya dari pada pekerjaannya di luar rumah. Berdasarkan kaedah fikih yang menyatakan menghilangkan mafsadat didahulukan dari mengambil manfaat. (Muhammad Bakri Ismail,1997:79)

Hukum bolehnya istri bekerja mencari nafkah akan berubah menjadi haram bila ia bekerja akan menimbulkan dampak negatif untuk keluarga dan tidak mampu memenuhi syarat-syarat yang digariskan dalam hukum Islam seperti:

1. Tidak mendapat izin dari suaminya, artinya suami melarang istri bekerja sehingga menyebabkan sering terjadi pertengkaran antara istri dengan suaminya.

2. Istri sibuk bekerja di luar rumah sehingga melalaikan tugas utamanya mengurus suami dan anak-anaknya.

3. Tidak mampu mewujudkan ketenteraman, keharmonisan, dan kasih sayang antara anggota kelurga di rumah tangga, yang akhirnya di akhiri dengan perceraian.

4. Pekerjaan yang dilakukan melanggar hal yang dilarang hukum Islam seperti bekerja di diskotik, di lembaga prostitusi dan lainlainnya yang diharamkan dan merupakan perbuatan maksiat.

5. keluarga terpecah karena suami istri sibuk bekerja dan anak-anak menjadi terlantar. 
Haramya istri bekerja di luar rumah berdasarkan pada ayat Alquran surat al-Ahzab ayat 33. Ayat tersebut dipahami dengan kaedah fikih"ketentuan atas sesuatu berdasarkan keumuman lafazh bukan dengan atas kekhususan sebab". Dalam kaedah lain disebutkan, "Hukum yang digantungkan kepada sesuatu syarat, tidak sah kecuali dengan terpenubi syarat itu." (Djazuli,2006:104). Juga kaedah "Segala mudharat harus dibindarkan sedapat mungkin".

Hadis dari Umamah riwayat ahmad menyatakan :

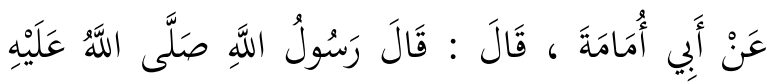

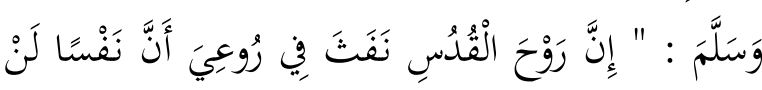

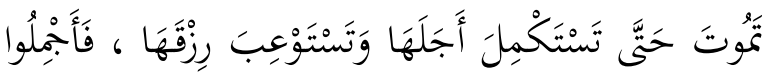

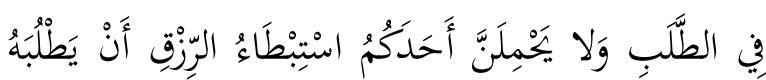

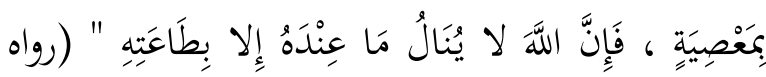

أحمد

Dari Abu Umamah ia berkata babwa Rasulullah Saw bersabda, "Sesunggubnya Rub al-Qudus Jibril AS) membisikkan padaku babwa seseorang tidak akan meninggal sampai sempurna ajal dan juga rezkinya. Oleh sebab itu, perbaikilah caramu untuk mendapatkan rezki dan jangan memperolehnya dengan bermaksiat. Sesunggubnya Allah tidak akan menerima kecuali dengan ketaatan." (HR. Ahmad)(Abu Abdullah al-Qadha'i,1986:221)

Hadis yang lain Rasulullah SAW bersabda:

عَنِ ابْنِ عُمَرَ عَنِ النَّبِّ -صلى الله عليه وسلم- : أَنَّ

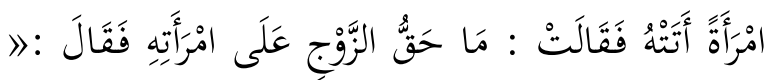

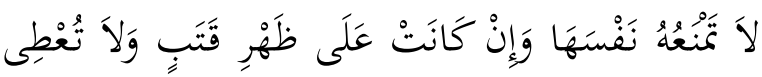

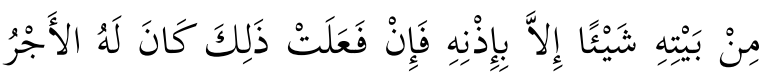

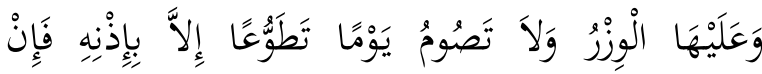

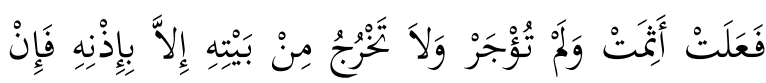

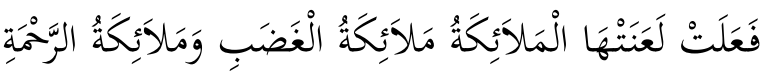

حَتَّى تَتَوبَ أَوْ تُرَاجِعَ 《. قِيلَ : وَإِنْ كَانَ ظَالِلمًا قَالَ

$$
\text { ا وَإِنْ كَانَ ظَالِلمًا 《) (رواه البيهقي) }
$$

Dari Ibnu Umar Ra bahwa seorang perempuan mendatangi Rasulullah Saw dan berkata, Apa hak seorang suami dari istrinya. Rasulullah Saw bersabda, Jangan engkau menghalanginya untuk mendekatimu (bergaul) dan jangan memberikan sesuatu kepada orang lain dari rumahnya tanpa seizinnya. Jika dilakukan yang demikan maka bagimu pabala dan jika kamu langgar maka kamu berdosa. Jangan kamu melakukan puasa sunat kecuali dengan ižinnya, jika kamu lakukan maka kamu berdosa, jangan kamu menyewa (mempekerjakan orang lain) dan jangan kamu keluar dari rumah kecuali atas iz̨innya. Jika kamu lakukan maka bagimu laknat malaikat, malaikat gadhab (pemarah) dan malaikat rahmah sampai kamu bertaubat atau kembali. Ada yang mengatakan, meskipun suami itu zhalim. Rasulullah Saw menegaskan, meskipun ia zhalim. (HR. Baihaqy)

Hadis yang pertama melarang melakukan pekerjaan yang dalam bentuk maksiat dan hadis yang kedua meyatakan tugas utama istri melayani suami, bila istri keluar rumah harus izin suaminya. Bila istri melanggar larangan suaminya malaikat melaknatnya sampai istri taubat. Keharaman istri mencari nafkah dalam kondisi ini dikaitkan dengan maqashid syariah adalah dalam keadaan memelihara agama, yang berdasarkan ayat dan hadis di atas.

\section{KESIMPULAN}

Hukum istri mencari nafkah bervariasi ,hukum asal istri mencari nafkah di luar rumah tangganya adalah ibahah (boleh), karena masalah ini tidak ada nash secara jelas yang mengaturnya. Tidak ada larangan dan juga tidak ada suruhan. Hukum berubah menjadi sunah Istri bekerja mencari nafkah merupakan solusi membantu suami mengatasi ketidak mampuan memenuhi kebutuhan keluarga. merupakan faktor utama untuk memperoleh penghasilan dan unsur penting untuk memakmurkan anggota keluarga., hal ini hanya merupakan kebutuhan setingkat haji 
belum sampai daruri. Apabila suami tidak membutuhkan bantuan dari istri untuk mencari nafkah, niat istri bekerja hanya untuk meningkatkan status sosial,yang merupakan pelengkap ( tahsini) maka hukum istri bekerja di luar rumah tangganya berubah menjadi makhruh. Hukum boleh istri bekerja mencari nafkah akan berubah menjadi haram bila ia bekerja akan menimbulkan dampak negatif untuk keluarga dan tidak mampu memenuhi syarat-syarat yang digariskan dalam hukum Islam dalam artian melanggar aturan agama yang termasuk dharuri. 


\section{DAFTAR KEPUSTAKAAN}

Ali bin Ahmad bin Sa`id bin Hazm, al-Muhalla, Cairo: Mathba`ah al-Nahdhah, $1347 \mathrm{H}$

Abu al-'Ala Al-Maududi, dikutip oleh M.Quraish Shihab dalam buku, Perempuan Islam di Indonesia dalam Kajian Tekstual dan Kontekstual, Jakarta: INIS, 1993

Abu Bakar Muhammad bin Al-'Arabi, Abkan Alquran, Cairo: Maktabah al-Baby al-Halaby, 1957 ,jilid, III,

Abu Syuqqah, Tabrir al-Mar'ah fi 'Ashr al-Risalah, Alih bahasa Mujiono dengan judul, Jati Diri Perempuan Menurut Alquran dan Hadis, Bandung: Al-Bayan, 1996

Ali MutakinVol. 19, No. 3, (Agustus, 2017), pp. 547-570

al-Syâthibî, al-Muwâfaqât fi Ushûli al-Syarîah, Beirut: Dar al-Ma'rifah, 1992

Djazuli, Kaidah-Kaidah Fikih: Kaidah-Kaidah Hukum Islam dalam Menyelesaikan Masalah-Masalah yang Praktis, Jakarta: Kencana, 2006

Fakhr al-Dîn al-Râzi, 1999, al-Mahshûl fi Ilmi Ushûl al-Fiqh, Dâr al-Kutub, Juz II, Bayrut.

Fathi Daryni, 1975, al-Manâhij al-Ushûliyyah fî Ijtihâd bi al-Ra’yi fî al-Tasyrî’ . Dâr al-Kitâb al-

Ghafar Shidiq, 2009, “Teori Maqâshid al-Syarî‘ah Dalam Hukum Islam”, dalam Jurnal Sultan Agung, Vol XLIV No. 118 Juni-Agustus

Hans Wehr, 1980, A Dictionary of Modern Written Arabic, J. Milton Cowan (ed). Mac Donald dan

Ibnu al-Manzûr, 1972, Lisân al-'Arab. Dâr al-Fikr, Juz II, Beirut.

Ibnu Hajar Asqalani, Fathu Bari Syarbi Syahrah al-Bukhari, Beirut: Dar al-Fikr, 1993, jilid I

Ibnu Kasir, Tafsir Ibnu Katsir, Beirut: Dar al-Fikr, 1986, jilid III

Ibnu Qayyib al Jauziyah, I'Lam al-Muwaqi'in, Beirut: Daar al-Kutub al-Ilmiyah, 1996

Innovatio,Islam Masa Kini”, dalam jurnal, Vol. 6, No. 12, Edisi Juli-Desember.

Izzudin bin Abi Salam, Qqwqid al-Ahkeam fi Masalih al-Anam, Beirut,Dar Kutub al-Ilmiyah, 1999

Jurnal Ilmu Hukum. Fakultas HukumUniversitasSyiah Kuala, Banda Aceh. 23111. ISSN: 08545499 |e-ISSN: 2527-8482. Kanun JurnalIlmu HukumTeoriMaqashid Al Syariah dan Hubungannya dengan MetodeIstinbath Hukum

GhafarShidiq, “Teori Maqâshid Al-Syarî’ahDalamHukum Islam”, dalamJurnal Sultan Agung, Vol XLIV

M. Ali Hasan, Perbandingan Madhhab. Raja Grafindo Persada, Jakarta, 2002 
M. Quraish Shihab, Tafsir Al-Misbah,Jakarta: Lentera Hati, 2004,

M.Quraish Shihab, Wawasan a-Qur'an, Bandung: Mizan, 1996

Mahmud Syalthûth, 1966, Islâm: ‘Aqî̀ah Wa Syarî’ah. Dâr al-Qalam, Kairo.

Mohammad Darwis, "Maqâshid al-Syarîah dan Pendekatan Sistem Dalam Hukum Islam ,2012

Muhammad bin Ismai il bin al-Mughirah al-Bukhary, Shahih al-Bukhary,Cairo: Dar al-Sya ab, 1987

Muhammad Idris al-Marbawiy, tt, Kamus Idris al-Marbawi; Arab-Melayu. al-Ma’arif,

Nasaruddin Umar, Argumen Kesetaraan Jender Perspektif Al-Quran, Jakarta: Paramadina, 1999

Satria Effendi, “Dinamika Hukum Islam” dalam Tujub Puluh Tabun Ibrobim Hosen. Remaja , 1990

Syihab al-Dîn Ahmad ibn Idrîs al-Qarafy, Anwâr al-Burûq fì Anwa’ al-Furûq. Dâr al, 1344 H

Tahir ibn Ashur, Maqâshid al-Syarîah al-Islâmiyah. Dâr al-Salam, Kairo,2009

Wahbah al-Zuhaili, Nadhriyatu al-Dharuriyah al-Syar'iyah, penerjemah Sayid

Wahbah al-Zuhaili, Ushûl al-Fiqh al-Islâmi, Dâr al-Fikri, Damaskus, 1986 